\title{
Erodibility of soft fresh water sediments: the role of bioturbation by meiofauna
}

\author{
M. A. de Lucas ${ }^{1}$, M. Bakker ${ }^{1}$, J. C. Winterwerp ${ }^{1}$, T. van Kessel ${ }^{2}$ and F.Cozzoli ${ }^{3}$ \\ ${ }^{1}$ Environmental Fluid Mechanics, Delft University of Technology, 2628CN, Delft, The Netherlands, m.a.delucaspardo@tudelft.nl \\ ${ }^{2}$ Sediment Transport and Morphology, Deltares, 2629HD, Delft, The Netherlands \\ ${ }^{3}$ Netherlands Institute of Sea Research (NIOZ) 4400 AC Yerseke, The Netherlands
}

\begin{abstract}
Markermeer is a large and shallow fresh water lake in The Netherlands. It has a $680 \mathrm{~km}^{2}$ surface and a $3.6 \mathrm{~m}$ mean water depth. Markermeer is characterized by its high turbidity, which affects the lake ecosystem seriously. As part of a study that aims to mitigate this high turbidity, we studied the water bed exchange processes of the lake's muddy bed. The upper cm's - dm's of the lake bed sediments mainly consist of soft anoxic mud. Recent measurements have proved the existence of a thin oxic layer on top of the soft anoxic mud. This oxic layer is believed to be responsible for Markermeer high turbidity levels. Our hypothesis is that the oxic layer develops from the anoxic mud, and due to bioturbation. In particular we will refer to bioturbation caused by meiobenthos. The objective of this study is to determine the influence of the development of the oxic layer on the water-bed exchange processes, as well as the role of bioturbation in this processes. This is done by quantifying the erosion rate as a function of bed shear stresses, and at different stages of the development of the oxic layer. Our experiments show that bioturbation increases the erosion rate of Markermeer sediments, and therefore affects the fine sediment dynamics of the lake.
\end{abstract}

\section{INTRODUCTION}

Markermeer is a large artificial fresh water lake located in the centre of The Netherlands. Together with the northern IJselmeer it is the largest natural fresh water reservoir of Europe. This area is known as the IJselmeer Region. During the last decades, the lake has experienced a decrease in its ecological values. [Noordhuis \& Houwing, 2003; van Eerden \& van Rijn, 2003]. This is may be caused by a food web that is not functioning optimally. Fine sediments, which are in significant concentrations in the water column, are considered to be an important pressure on the food web of the lake [Van Kessel et al, 2008]. Moreover, water quality problems are often related to sediment composition and transport in Markermeer [Van Duin, 1992]. Therefore, fine sediments in the system seem to be a key factor towards an explanation of the negative trend over the last decades. As a part of a study that aims to mitigate Markermeer high turbidity, we studied the water bed exchange processes of the lake's muddy bed.

The upper cm's - dm's of the lake bed sediments mainly consist of soft anoxic mud. Recent measurements have proved the existence of a thin oxic layer on top of the soft anoxic mud. Thin oxic layers on the mud surface exert a pronounced influence upon the exchange of substances across the mud water interface [Mortimer, 1942]. In fact, the sediment concentration in Markermeer's water column is dominated by erosion and sedimentation of this oxic layer [Vijverberg, 2008]. Our hypothesis is that the oxic layer develops from the anoxic mud. The main mechanism responsible for the development of the oxic layer would be bioturbation.

Bioturbation includes the processes of feeding, burrowing and locomotory activities of sediment dwelling benthos [Fisher \&
Lick, 1980]. The activity of this benthic biota severely affects sediment dynamics [Le Hir et al., 2007]. Previous researchers have measured the effect of bioturbation in the erodibility of sediments [Willows et al., 1998; Widdows et al., 1998 and 2000; Amaro et al., 2007]. The erodibility of sediments was characterized through the turbidity of the water in an annular flume. Our approach focuses on quantifying the erosion rate as a function of bed shear stresses. We quantified those erosion rates at several time stages within the development of the oxic layer. Our aim is a better understanding of the physics associated to bioturbation driven erosion.

\section{MARKERMEER PHYSICAL DESCRIPTION}

Lake Markermeer did not existed before the 20th century. The IJsselmeer Region used to be the Zuiderzee, a shallow inlet from the North Sea of about $5000 \mathrm{~km}^{2}$. During the Zuiderzee era there was a landward fine sediment flux, caused by tide and estuarine circulation. Thick layers of clay and loam were deposited as a result of this flux. Then in the 20th century, the Zuiderzee works took place, and the morphology of the region changed significantly. Figure 1 illustrates the differences in bottom composition between the two periods, as well as the differences in morphology. Markermeer was created in the upper reaches of the old sea inlet, with finer bottom sediments and smaller depths than the northern IJsselmeer. The dike separating the lakes, known as the Houbtrijdijk, does not allow for the fine sediments to be transported outside of Markermeer anymore.

Markermeer is a shallow lake, with a mean water depth of 3.6 m. About $90 \%$ of the lake has a water depth between 2 and $5 \mathrm{~m}$ [Vijverberg, 2008]. The total surface of water, including Lake IJmeer, is $691 \mathrm{~km}^{2}$ [Coops et al, 2007]. The volume of stored 


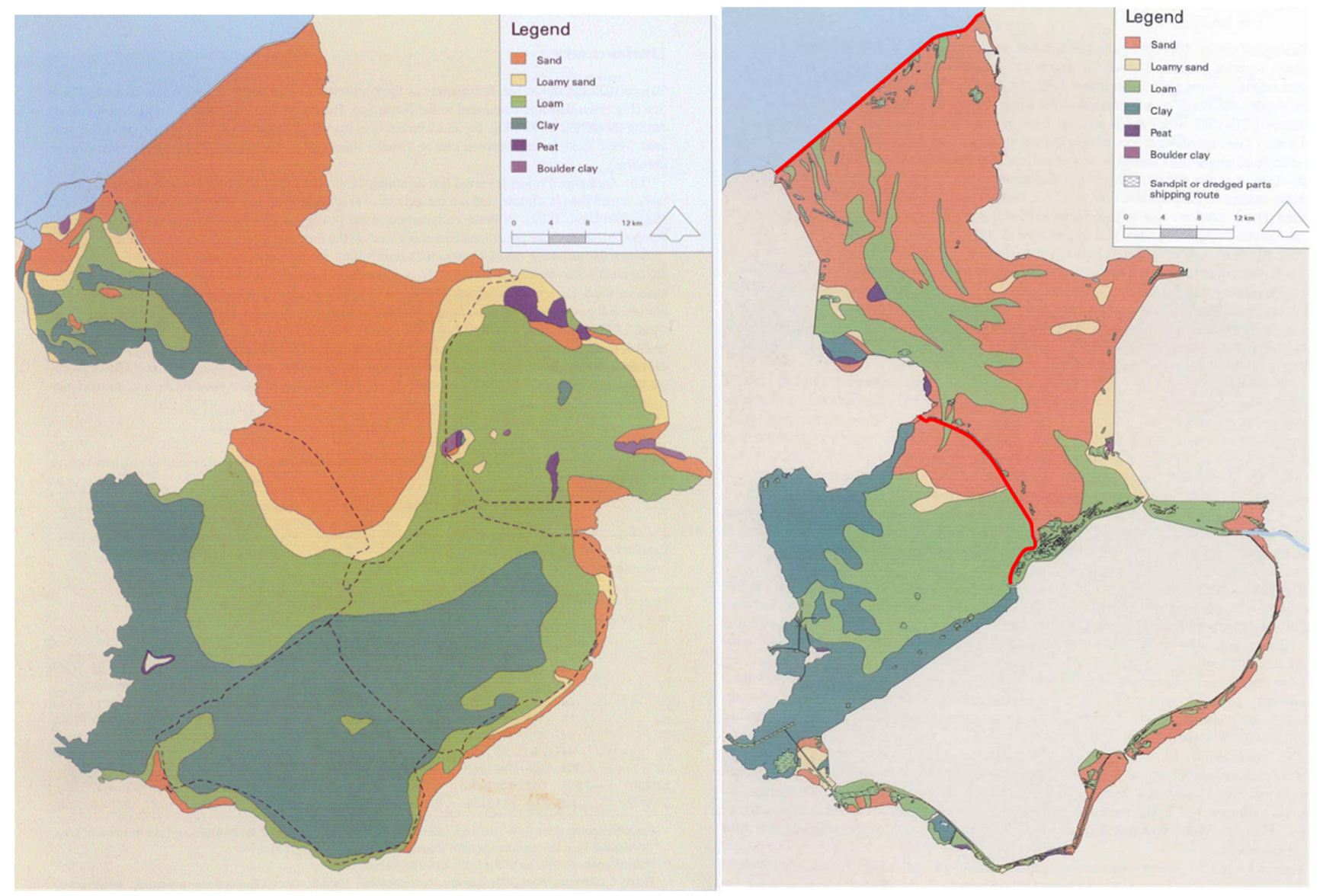

Figure 1. The left panel shows the sea inlet bottom composition during the Zuiderzee era. The right panel shows the current Markermeer bottom composition, after the execution of the Zuiderzee works [Lenselink \& Menke, 1995]. Green represents loam and dark green represents clay.

water is about $2.510^{9} \mathrm{~m}^{3}$ [Van Duin, 1992]. The residence time ranges between 6 and 18 months [Vijverberg, 2008]. The water temperature during 2010 was $13.6 \pm 5.4^{\circ} \mathrm{C}$.

The large scale flow pattern in Markermeer is mainly dominated by wind induced flow [Vijverberg, 2008]. Wind induces horizontal circulations of water. This circulations may have opposite directions in surface and near the bottom, which results in a

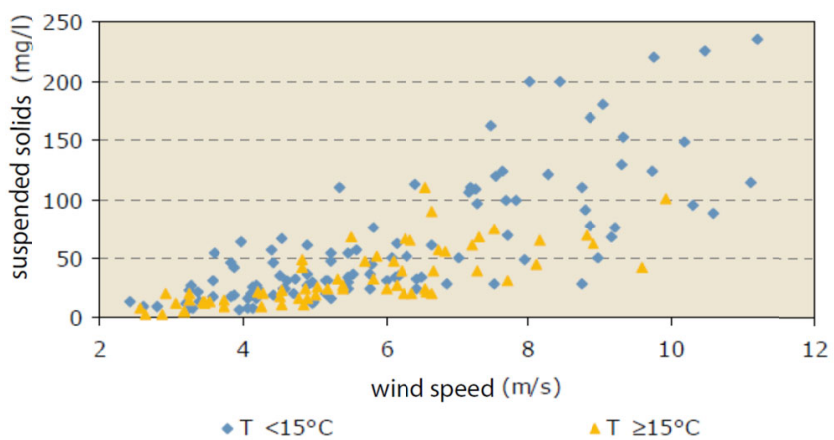

Figure 2. Relationship between wind speed and suspended solids in Markermeer [Noordhuis, 2010] complex 3D flow pattern [Vijberverg, 2008]. Different large scale circulation patterns can occur depending on wind direction [van Kessel et al, 2008]. This water circulation is responsible for the fine sediment transport over the system. Wind also generates waves which, together with currents, induce bed shear stresses that may resuspend sediments from the bed of the lake. The relationship between wind speedl and suspended solids in Markermeer is shown in Figure 2. Wind-induced-waves have a more important effect on the re-suspension of sediments from the bed than wind-induced-currents in Markermeer [Royal Haskoning $\&$ WLDelft Hydraulics, 2006].

\section{METHODS}

Markermeer anoxic mud sediment samples were placed in cylindrical containers, with Markermeer water on top. These containers were kept in a small chamber, in which temperature and light conditions were controlled to mimic field conditions. We choose $6.5{ }^{\circ} \mathrm{C}$ and no light exposition. An initial erosion experiment was performed to every anoxic mud sample. Then several individuals of Tubifex, a characteristic benthic species of Markermeer, were added to the sample. The Tubifex individuals were obtained by sieveing oxic mud through $250 \mu \mathrm{m}$ and $500 \mu \mathrm{m}$ sieves. The oxic mud started to develop on top of the anoxic mud, 
upon which a series of erosion experiments was executed. The erosion rate under several bottom shear stresees was determined with these experiments. The samples were tested at several stages within the oxidized layer development process. A defaunated control sample was also studied for its erodibility. This sample was defaunated with Gamma Rays treatment in the Nuclear Reactor Institute Delft. The erosion experiments were performed in an UMCES-Gust Erosion Microcosm System. This microcosm was calibrated at Deltares. The resulting calibration curve can be seen in Figure 3. An OSLIM turbidity meter was installed at the suction outlet of the microcosm, with which the turbidity of the out-flowing water was measured. The turbidity meter was calibrated with samples of different concentrations of the sediments to be tested. Equation 1 shows how the eroded mass was calculated from the turbidity data:

$$
E=c \cdot Q \cdot \Delta t
$$

Where $\mathrm{E}$ is the eroded mass $(\mathrm{g}), \mathrm{c}$ is the sediment concentration $(\mathrm{g} / \mathrm{l})$ in the out-flowing water, $\mathrm{Q}$ is the discharge $(1 / \mathrm{s})$ of water through the suction outlet, and $\Delta \mathrm{t}(\mathrm{s})$ is the interval between two measurements of the turbidity meter. The erosion rate $\left(\mathrm{g} / \mathrm{m}^{2} \mathrm{~s}\right)$ was then calculated by means of dividing the eroded mass by the surface of the microcosm bed, and by the number of seconds within each bed shear step.

We performed erosion experiments at 2, 4, 6 and 8 days since the beginning of the bioturbation process. The same measurement frequency was applied for the defaunated sample.

\section{RESULTS AND ANALYSIS}

Figure 4 shows the results of our first set of experiments. The erosion rate of a two days-old oxic layer, is larger than the erosion rate of an anoxic layer. This holds for most of the bed shear stresses applied. The erosion rate of a four days-old oxic layer, is larger than the erosion rate of an two days-old oxic layer. This also holds for most of the tested bottom shear stresses. However, the erosion rate of a six days-old oxic layer is larger than the erosion rate of a four days-old oxic layer only for $0.8 \mathrm{~Pa}$. This is probably caused by the high mortality of Tubifex in the six days oxic layer experiment. Finally the erosion rate of an eight days old oxic layer is larger than the erosion rate of a six days old oxic layer. This holds for most of the tested bottom shear stresses.

The oxic layer thickness was $1 \mathrm{~mm}$ after two days, $1.3 \mathrm{~mm}$ after four days, $2 \mathrm{~mm}$ after six days, and $2.5 \mathrm{~mm}$ after eight days. The erosion rate of the defaunated sample was always between 0 and $0.1\left(\mathrm{~g} / \mathrm{m}^{2} \mathrm{~s}\right)$ for every bottom shear stress, and it did not show any time evolution. An oxic layer did developed on the defaunated sample as well. However, its thickness was $1 \mathrm{~mm}$ only, and constant over time. We believe that the oxic layer in the defaunated sample was caused by the diffusion of oxygen only.

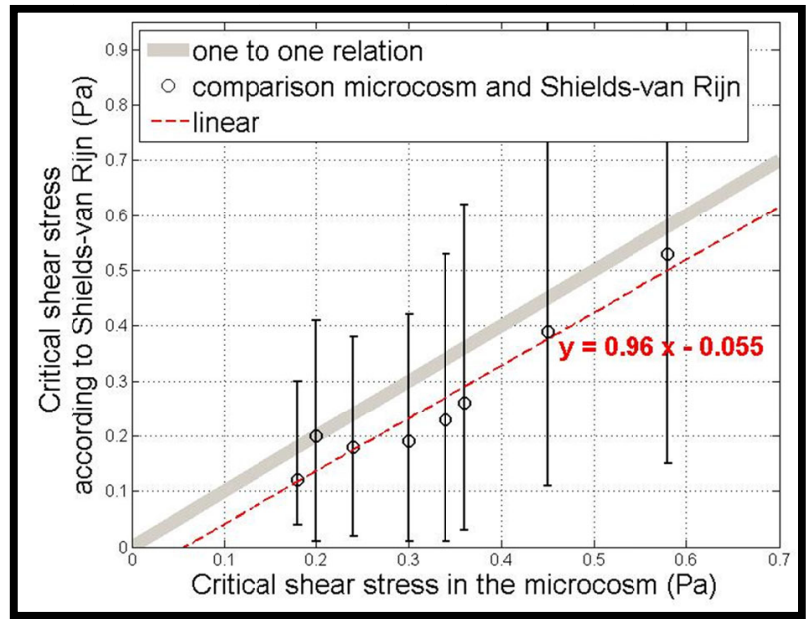

Figure 3. Calibration curve of the UMCES-Gust Erosion Microcosm System. The error bars were calculated by using d10 and 190 (instead of d50) for the calculation of the critical shear stress according to Shields-van Rijn.

\section{DISCUSSION}

Overall we can conclude that bioturbation increases the erosion rate of Markermeer sediments under bottom shear stresses of 0.4 to $0.8 \mathrm{~Pa}$. The larger the bioturbation time, the larger the increase in erosion rate. The defaunted sample did not experienced any increase in erosion rate over time under any of the studied bottom shear stresses. Thus oxidation can not be responsible of the decrease in bed shear strength.

The results has important implications for the fine sediment dynamics of Markermeer. Without biota effects, significant erosion of the bed, and therefore a turbid water column, would only be possible under bed shear stresses larger than $0.8 \mathrm{~Pa}$. Waves larger than $0.8 \mathrm{~m}$ would be needed for producing a $0.8 \mathrm{~Pa}$ bottom shear stress (given a wave period of $5 \mathrm{~s}$, a sediment bed with a d50 of $80 \mu \mathrm{m}$, and a depth of 3 meters). Those wave heights occur only under storm conditions in Markermeer. However, the reality is that Markermeer is characterized by a high turbidity. Therefore, and given the very particular characteristics of Markermeer (e.g. shallowness, muddy bottom), the benthic fauna is causing a major contribution for the characteristic turbid state.

\section{ACKNOWLEDGEMENT}

The authors thanks to Peter Herman, Gerard Kruse, Bram van Prooijen, Marinus Hom and Ruurd Noordhuis for the support and guidance on this paper and related work. 


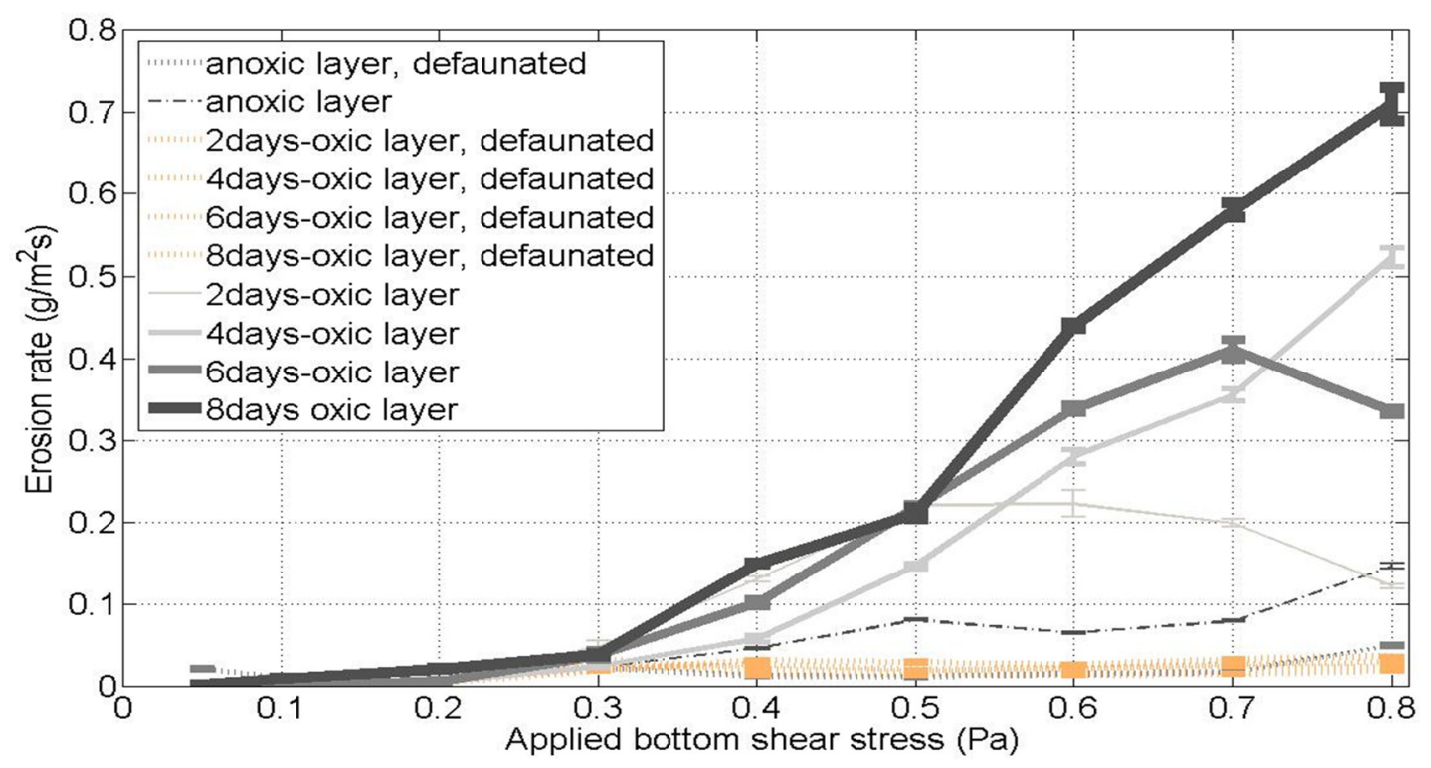

Figure 4.Effect of bioturbation on the erodibility of Markermeer sediments.

\section{REFERENCES}

Noordhuis R, Houwing EJ (2003) Afname van de Driehoeksmossel in het Markermeer. RIZA rapport 2003.016.

van Kessel T, de Boer G, Boderie P (2008) Calibration suspended sediment model Markermeer. Deltares report Q 4612.

van Eerden M, van Rijn S (2003) Redistribution of the Cormorant population in the Ijsselmeer area. CRGB 5: 33 - 37.

van Duin E H S (1992) Sediment transport, light and algal growth in the Markermeer - $a$ two dimensional water quality for a shallow lake. Ph.D. thesis, Wageningen University.

Vijverberg, T. (2008). Mud dynamics in the Markermeer. MScthesis Delft University of Technology, Delft, The Netherlands.

Mortimer, C. H. (1942). The Exchange of Dissolved Substances Between Mud and Water in Lakes. The Journal of Ecology 30.1: 147-201.

Fisher, J. B. and Lick, W.J. (1980). Vertical mixing of lake sediments by tubified oligo-chaetes. J. Geophysical Research, 85: 3997--4006.

Hir, P. L., Y. Monbet, and F. Orvain (2007). Sediment erodability in sediment transport modelling: Can we account for biota effects? Continental shelf research.

Willows, R., J. widdows, and R. Wood (1998). Influence of an infaunal bivalve on the erosion of an intertidal cohesive sediment: A flume and modelling study. Limnology and Oceanography 43 (6), 1132-1343.

Widdows J., Brinsley M. D., Salkeld P. N., Lucas C. H. (2000). Influence of biota on spatial and temporal variation in sediment erodability and material flux ona tidal flat (Westernschelde, The Netherlands). Marine Ecology Progress Series 194: 23-37
J. Widdows, M.D. Brinsley, N. Bowley, C. Barrett (1998). A benthic annular flume for in situ measurement of suspension feeding/biodeposition rates and erosion potential of intertidal cohesive sediments. Estuarine, Coastal and Shelf Science, 46 (1) (1998), pp. 27-38

Amaro T P F, Duineveld C A, Bergman M J N, Witbaard R, Scheffer $M$. the consequences of changes in abundance of Callianassa subterranea and Amphiura filiformis on sediment erosion at the Frisian Front (south-eastern North Sea). Hydrobiologia (2007) 589:273-285.

Coops H, Kerkum FCM, van der Berg MS, van Splunder I (2007) Submerged macrophyte vegetation and the European Water Framework Directive: assessment of status and trends in shallow, alkaline lakes in the Netherlands. Hydrobiologia (2007) 584:395-402.

Royal Haskoning \& WL Delft Hydraulics (2006), Verdiepingsslag en maatregelen slibproblematiek Markermeer - Analyse kennisleemten en inventarisatie maatregelen, authors Van Ledden et al, Royal Haskoning and WL Delft Hydraulics.

Lenselink G, Menke U. Atlas geology and soil of the Markermeer. Rijkswaterstaat, Directie IJsselmeergebied.

Noordhuis R (2010). Ecosysteem IJsselmeergebied: nog altijd onderweg. Trends en ontwikkelingen in water en natuur van het Natte Hart van Nederland. Rijkswaterstaat Waterdienst. 